\title{
LOW COST IOT SYSTEM FOR THE ASSET CONTROL SUPPORT BASED ON BARCODE SCANNING
}

\section{T. Vince, L. Belay}

Technical University of Košice

Letná, 9, 042 00, Košice, Slovak Republic. E-mail: tibor.vince@tuke.sk, lukas.belay @ student.tuke.sk

Purpose. The goal of the paper is to describe analysis and implementation IoT system for support the asset control via barcode scanning. Originality. The paper deals with the research on surveys for development an IoT device for searching correct store location of the devices in the laboratory and support asset checking for selected location. Methodology. The paper proposes one of the possibilities for development an IoT device basing on ESP8266 using Nextion intelligent display and a Windows application developed using C\#. Retrieving data from a remote database, the application updates the data from central server. Authors described the whole development process starting from computer design of the proposed IoT device, chose the elements for hardware unit, design and implementation the Windows application and also experimental verification of derived results. Result. In this work authors proposed experimental sample of IoT system for the asset control via barcode scanning. The client-server application was designed to support the control of property records with the design of IoT equipment. The design of IoT devices is realized by modular connection of components. By implementing the GUI on the display, it is possible to control the reader module and observe the records in the informative mode and the control mode. 3D models are a device in a housing, where the output is a display. Using developed application, it is possible to connect to an IoT device and perform asset registration control by communicating with each other. This system implements all theoretical results described in the paper, and confirms them basing on the experiments provided. Practical value. Proposed IoT system could be practically used in university laboratories to control equipment location at any moment of time. References 11, figures 14 .

Key words: C\#, IoT, Nextion, ESP8266, barcode.

\section{МАЛОБЮДЖЕТНА ІОТ-СИСТЕМА ДЛЯ КОНТРОЛЮ ОБЛАДНАННЯ НА ОСНОВІ СКАНУВАННЯ ШТРИХ-КОДУ}

\section{Т. Вінсе, Л. Белай}

Технічний університет Кошице

вул. Лєтня, 9, м. Кошице, 04200, Словаччина. E-mail: tibor.vince@ tuke.sk, lukas.belay @ student.tuke.sk

Робота присвячена аналізу роботи та впровадженню ІоТ системи для підтримки контролю наявного у лабораторії обладнання на основі сканування штрих-коду. У статті наведено результати аналізу можливості розробки ІоТ-пристрою для пошуку правильного місця зберігання приладів у лабораторії та підтримки перевірки належності певного пристрою до обраного місця розташування. Запропоновано один з можливих варіантів розробки ІоТ-пристрою на основі мікроконтроллера ESP8266 з використанням «розумного» дисплею Nextion та Windows-застосунку, розробленого за допомогою мови програмування С\#. Отримуючи дані 3 віддаленої бази даних, застосунок оновлює базу даних ІоТ пристрою з центрального сервера. Автори описали увесь процес розробки починаючи з комп'ютерного моделювання запропонованого ІоТ-пристрою, вибору елементної бази, проектування та розробки Windows-застосунку та експериментальні дослідження отриманих результатів. У роботі запропоновано експериментальний зразок ІоТ-системи для допомоги контролю пристроїв та приладів у лабораторії на основі сканування штрих-коду. Для підтримки контролю коректності записів у базі даних ІоТ-пристрою було розроблено відповідний клієнт-серверний застосунок. Структуру IоТ-пристроїв реалізовано на основі принципу модульного з'єднання компонентів. Застосовуючи графічний інтерфейс користувача, $є$ можливим керувати модулем зчитування та читати записи у базі даних у інформаційному та керувальному режимах. Для дисплею створені тривимірні моделі помешкання, у яких відображуються розташування контрольованих приладів. Використовуючи розроблений застосунок, $є$ можливим з'єднуватись 3 ІоТ-пристроєм та виконувати реєстрацію приладів та керувати ними шляхом комунікації приладів між собою. Розроблена система впроваджує усі теоретичні результати досліджень, описані у статті, та підтверджує іх на основі проведених експериментів. Запропонована ІоТ-система може набути практичного використання, наприклад, для контролю місцезнаходження обладнання у лабораторіях університету у будь-який момент часу.

Ключові слова: C\#, IoT, Nextion, ESP8266, штрих-код.

PROBLEM STATEMENT. When many devices are shared at workplace or laboratories, it is mandatory, that all devices and different equipment has own place to be stored. The laboratory equipment may vary so also the location of the devices could be change. It is than very helpful, when the users can easily find information of the correct location. Also it is very helpful for the authorized person to have easy way to check, if all devices are on correct location.

To support such a device and equipment location handling, special IoT device is proposed and implemented. By retrieving data from a remote database, the application would be able to update the data from central server. This process of creating, whether devices or applications is possible in several ways. The design includes several factors and problems 
to be solved. The aim of this project is the ability of IoT devices to scan a barcode and provide information on the display of the device. When using Windows application, it would be possible to download content from a remote database and use it without a connection with the central server. In this way, it would be possible to perform an inspection, and save or export results of the performed inspection. It is important to select components to build an IoT device that can interfere with size and mobility. The paper is divided into several chapters, where each chapter deals with a different issue or process of this issue. The result is the design and implementation of a mobile IoT device with a controllable display and an application that will be able to connect to the device, control the barcode reader and perform the control itself. By retrieving data from a remote database, the application will be able to update the data for an asset inspection. When connecting the application, it would be possible to download content from a remote database and use it for personal purposes without an internet connection. In this way, it would be possible to perform an inspection, save an inspection or export data on the performed inspection. It is important to select components to build an IoT device that can interfere with size and mobility. For a more efficient use of the device, a touch screen to control the barcode reader would be suitable, eliminating several analogue controls for the device. The paper is divided into several chapters, where each chapter deals with a different issue or process of this issue.

\section{EXPERIMENTAL PART AND RESULTS} OBTAINED.

\section{Analysis of $H W$ requirements}

The result of the work should be an IoT device that would communicate with a central server and also desktop application. The IoT device consists of several elements.

First is a suitable barcode reader for the purposes of property identification, which is one of the main parts of the project. The hardware part should perform a function the barcode scanning process. For this, it is necessary to implement a barcode scanning module that should meet certain criteria. For everyday use in practice, the reader needs to be available in areas harder to reach. It means small sized barcode scanners. Another important criterion is to implement a module capable of reading $1 \mathrm{D}$ of a barcode standard - Code 128. This barcode standard is used at the Technical University of Kosice identification plates. The module must meet the possibility of a communication interface supporting standard microcontrollers, such as UART, SPI, I2C, etc. It is essential that the required module can be connected to the rest of the hardware and communicate with the microprocessor. It is advisable to connect the module to the microcontroller using a flexible conductor. The production process can go up to the mass production of the product and in this case the price is a very important factor, so another requirement is to choose low cost but reliable model.

The most important part of the device is the IoT microcontroller, which would be used to communicate with the application itself to support asset identification. The device should communicate with the application and directly with the server via $\mathrm{Wi}-\mathrm{Fi}$. The price is also a very important factor for this device, so it is necessary to choose a device that is not financially demanding. It also needs to be easy to use every day. Nowadays, the use of wireless devices is a big trend. These wireless devices can be powered by internal battery power. It is also a current trend, if we make such a demand, not to replace these batteries, but to recharge them using the AC/DC power adapter. The option for the equipment of this project is direct power via micro-USB cable, but this is not the best solution for our purposes. In case of power supply, it is required that the device be able to work with the micro-USB cable as well as the internal power supply.

Another requirement for an IoT device that would include the hardware part of the project is a device for displaying the necessary communication data with the user in graphical form. This device would be one of the available displays that can be connected to an IoT. It would also be useful if the display were to be touchsensitive and fit into a protective cover. Regarding the equipment requirements, all important criteria are mentioned, and a suitable requirement to be added to the criteria would be to provide a housing for the entire equipment. Individual parts of the device would thus be located together and would be protected in one part of the housing.

The whole system should consist of IoT device and Windows application to communicate with the IoT device.

The Windows application should enable communication with the IoT device over the network, it should enable data synchronization. It means update the data from centralized database to the local one. It is necessary that the application would work on isolated network without a direct connection to the central database. Another functionality in the application is the filtering of displayed devices by room, cabinet or the shelf. Another of the requirement is also a search by marking or entering the name of the device. These displayed results would be exported for the need to check the current state. This asset checking process may take a long time (few days), so it would be necessary to tear down the requirement to save and load the asset checking process. The result of the asset check process is the comparison of the list of facilities to be located on the site with those actually located there. One of the most important requirements in software analysis is to connect a Windows application with an IoT device and make the whole asset checking process available.

IoT device would contain several modules. It is necessary that these modules are compatible with the microcontroller. In previous chapter it was mentioned that the hardware part will contain a display. Displays that can be connected to an IoT device can be programmable (Smart Display). It would be advisable to choose the right display, which has a library for 
programming this display and an interface that fits our requirements. The requirement of the device is that the device must operate in 2 modes. These are called „location“ and "checking“ modes. In the first mode (location mode) after scanning the barcode, the device name, designation and location of the inspected device should appear on the display. In the second (checking) mode, the device would communicate with the Windows application to check if the devices are in correct location. The display should show the selected location to be checked, more precisely room, cabinet and shelf. It should also meet the requirement to display a list of devices to be present and a list of which devices have already been scanned. The display should also display the attributes of the connection such are IP address, Wi-Fi network name but also actual barcode value and so on.

Design of $\mathrm{Hw}$ part of the solution

The barcode reader is the core element of the hardware part of this project. There is a wide range of barcode readers that can be selected. According to analysis described in previous chapter, barcode scanner K-E1005 1D (Fig. 1) has been selected.

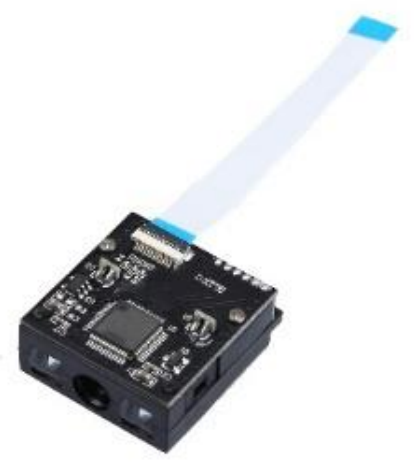

Figure 1 - K-E1005 1D barcode reader module

The module with the device can be inserted into a protective cover to keep all parts of the device together and mainly protected from external influences or it is possible to insert the module into the cover separately and another cover would contain the other part of the device. For more efficient use of the module, it is possible to separate the barcode reader from the device. Subsequently, it is necessary to interconnect the communication between the reader and the other hardware parts. The separation could be realized using a flex cable. In the first option it is necessary to provide a cover in which the entire part of the device will be inserted. In the second option, you will need to create a reader camera hole (scanning lens), indicator lights, and a flex cable hole to connect to the IoT. It is also necessary to make a hole for the cover of the other hardware part for the flex cable. A suitable solution would also be to implement a longer flex cable where the reader cover would be detached from the device cover and it would be able to access in less accessible places.

There are several options to meet the requirements for IoT microcontrollers for instance the Realtek RTL8710 microprocessor or ESP microcontroller family. The problem with Realtek microprocessor is complicated programming, and there is no high support available on the Internet, as there are no large communities about this microprocessor. Another suitable communication device is a device from Esspressif Systems, which has many ESP versions in its directory. Suitable ESP devices are ESP8266 or ESP32. After analysis ESP8266 NodeMCU development board was chosen. Fig. 2 shows the IoT ESP8266 NodeMCU pinout details.

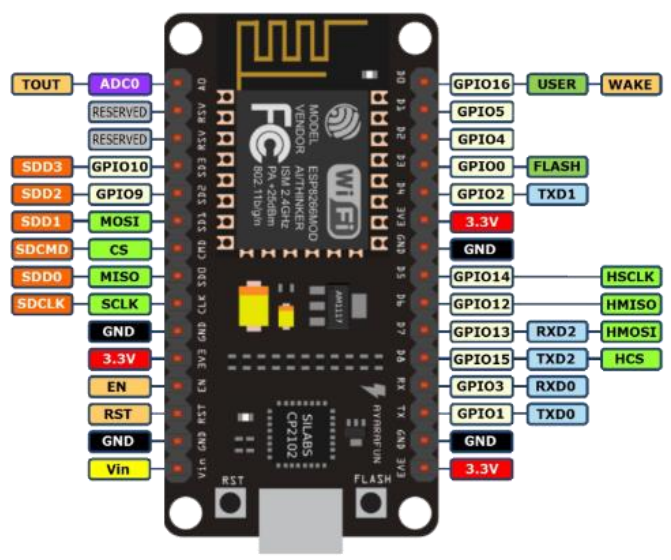

Figure 2 - ESP8266 NodeMCU pinout

There are a few ESP8266 manufacturers, but the most popular is the current Ai-Thinker. It is also a convenient device for communicating with the module and the output device through the GPIO pins. The module could be connected using the Software Serial Library and the display will be connected using power pins for power and ground, and subsequently the Rx and Tx communication pins.

IoT devices could be generally powered up via stable power source (for instance micro-USB) or battery source. If the device should be as universal as possible, both way of powering up should be implemented.

Lithium batteries would the most efficient for our purposes, as the lithium battery has a $3.7 \mathrm{~V}$ supply voltage and requires $3-3.6 \mathrm{~V}$ for IoT devices. This implies that the voltage value needs to be changed. This could be done using a DC/DC converter. These batteries would have the option of being charged or replaced. It will be possible to connect the batteries in series to achieve double the voltage or to connect in parallel to double the capacity of the batteries. The batteries can be inserted into the corresponding housing or soldered according to the desired needs mentioned above. Therefore, the possibility of lithium batteries that would power the entire hardware device is mentioned and there is the possibility of charging them using the TP4056 module, which also has a slot for micro-USB cable for 5 V DC voltage. For the TP4056, it will be necessary to create a hole in the device cover for the micro-USB slot to charge 18650 batteries. The options are to set the DC/DC converter output to $3.7 \mathrm{~V}$ or $5 \mathrm{~V}$. It will be more efficient to set the value to $5 \mathrm{~V}$ to power the IoT device, and the device will continue to power other parts of the hardware. 
Communication between the user and the IoT device is required. For this project it is suitable to use a display that serves as a GUI. It is a device that is more userfriendly and follows from the fact that it is communicable with the device, thus responding to instructions. The most suitable module that fits our requirements is the Nextion display with a 2.8 " screen size. This display belongs to smart display family. The Nextion display also allows UART communication and minimizes CPU usage by sending only instructions. It can display text, scrolling text, numbers, decimal numbers, buttons, progress bars, images and many other graphics control components but also allow use timers, variables etc. The display should show the data according to the selected mode. The data scanned by the barcode reader module, data from the Windows application as well as data from the central database will be displayed. To meet the requirements, the Nextion touchscreen has been selected, which has an HMI created in the Nextion editor to enable the use of IoT devices without a desktop application. The Nextion display is shown in Figure 3.

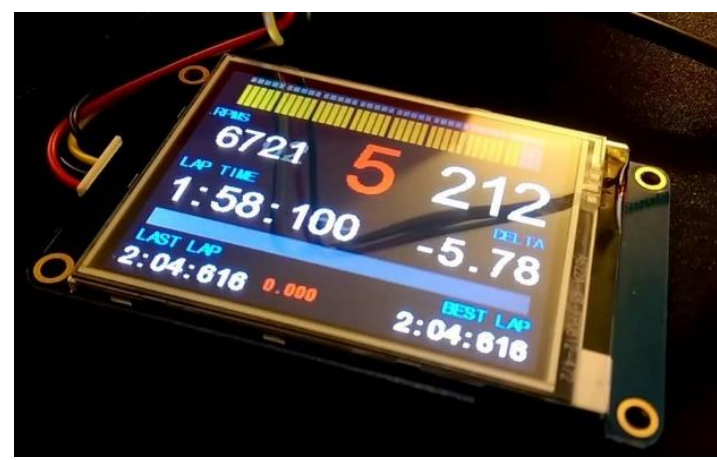

Figure 3 - Nextion display

The whole schematic interconnection of all modules is pictured on Figure 4.

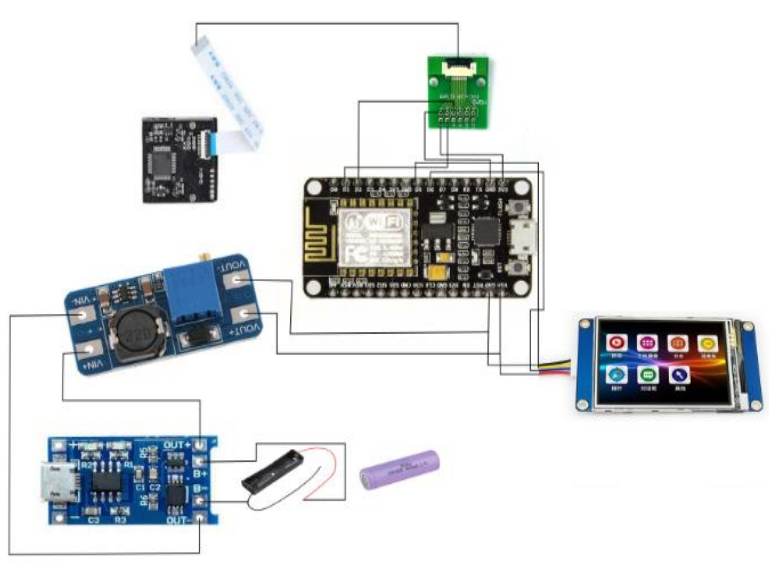

Figure 4 -Modules of the IoT device interconnection

The hardware part is composed of a barcode reader, a 12 pin FPC reduction, which is used to connect the barcode reader and the ESP8266 NodeMCU using a flex cable. Core of the IoT device is the microcontroller ESP8266 NodeMCU itself, which is used to communicate with the application using TCP/IP protocol. Another hardware part of this project is Nextion display. The hardware part is complemented by 18650 lithium batteries as well as the TP4056 charging module for these batteries. A DC-DC converter will be implemented between the batteries and the ESP to increase or decrease the voltage to power the overall hardware part.

\section{Cover design of the IoT device}

When solving the device with a suitable cover it is possible to choose different approaches, to obtain a cover suitable dimensions for our purposes.

For this task as a most effective way to create custom cover the 3D printing was selected. There are enough programs to design 3D models, so it would be advisable to design optimal model. Fusion 360 was used to design 3D models and to implement STL files into the program. Any model can be designed in the program, but limitations of the $3 \mathrm{D}$ printer have to be taking in to the account. The idea is to create multiple parts as a $3 \mathrm{D}$ models that would be printed in portions and later assembled as a one model.

The first element of the cover will be the cover for the display part of the device, which is the display from Nextion. Display Nextion have its own cover model, which the company offers on its site in the form of STL format file available for download. This cover will be screwed to the display. Also, the cover will then be screwed to the cover of the entire device. However, the Nextion cover file after import was modified for its own purposes, as this cover would be screwed to the main cover, several adjustments had to be made. The display cover and the Nextion display models are shown in Figure 5.

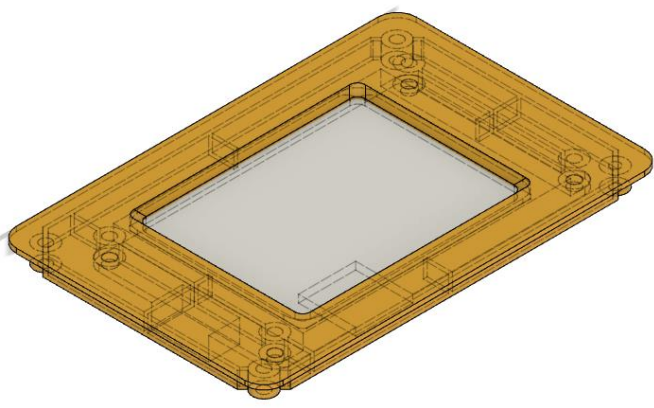

Figure 5 - Cover design for Nextion display

Another part of the 3D model is the cover for the barcode reader. However, there is no other part that is attached to this cover and will be used for insertion into the rails which are part of the large protective cover. It will serve as a holder where this barcode reader module can be stored. This cover consists of two parts to cover the barcode reader. The second part is attached to the larger part by insertion because it is designed so that the individual edges are close to each other with respect to the printing error with a deviation of $0.3 \mathrm{~mm}$. This deviation was only proposed after the first printing, 
where the design did not fit and the smaller cap could not be slid into a larger one where there was no space. The second design was corrected, where it was taken from the material and the narrower edge was pushed in successfully. The barcode reader cover design is shown in Figure 6. It shows the back of the cover on the right side of the figure for a barcode reader with a cut-out for the flex cable for interconnection with the main part of the IoT device.
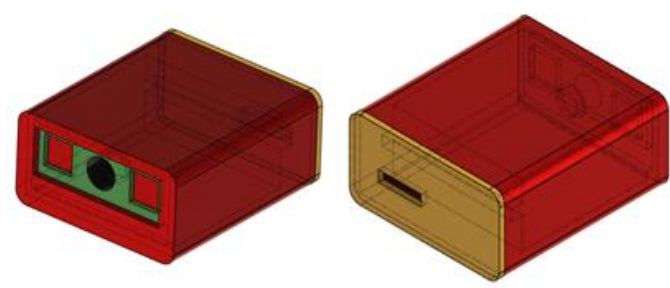

Figure 6 - Barcode reader cover design

The models of the IoT device parts are depicts in Figure 7. These parts will be located inside the main cover. Specifically a 5V-TP4056 charging module is shown. Lithium batteries 18650 with a capacity of $3.7 \mathrm{~V}$. For our needs a voltage of $5 \mathrm{~V}$ is required, this is resolved by adding to the circuit a DC boost converter that will be set to the output voltage of $5 \mathrm{~V}$. This model is not shown in the figure. The most important ESP8266 NodeMCU developing board.

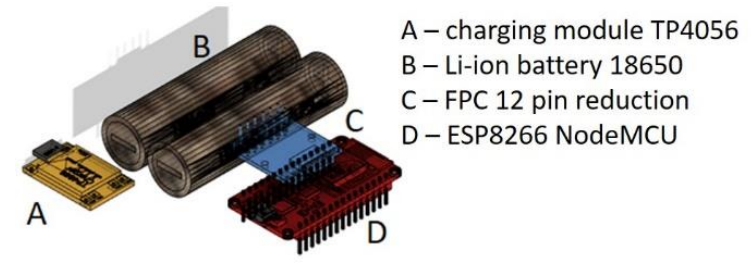

Figure 7 - IoT main part components model

The cover itself, which will cover all the components used in the project, is by its size considerably larger than the mentioned 3D models that are part of this project. Figure 8 shows a proposal for an overall design of a 3D model, where in addition to the above models, there is also a bottom cap that closes the overall cap from the bottom. It is a cover that slides into the large cover and a cover that is screwed to the large cover.

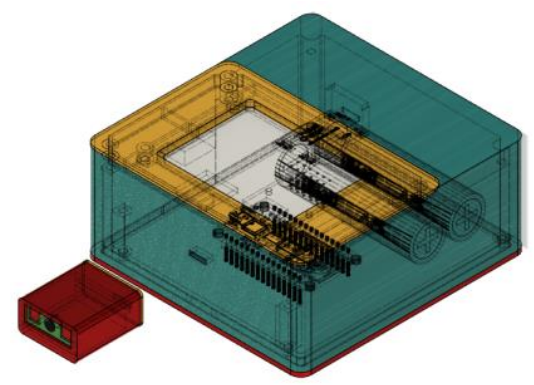

Figure $8-3 \mathrm{D}$ model design cover as a whole

\section{Design of the software part}

The software part of the project must be developed using several programming languages for the proper operation of IoT devices. The ESP8266 NodeMCU will be used, which can be programmed in several programming languages for example $\mathrm{C}++$ with Arduino libraries support - Wiring, C with RTOS (FreeRTOS) [1], MicroPython [3], LUA [2] or Assembler. Thanks to the open source Arduino platform, the Arduino IDE is well known and it can be program using $\mathrm{C}++$ with Arduino Wiring libraries.

Using Fusion 360 software, multiple 3D models will be designed to cover the hardware part of the project. These 3D models will need to be exported to STL format. The STL file format will then be implemented in the G3DMAKER program, which is used to create Gcode from the 3D model of the STL format. After creating the G-code and connecting the PC to the $3 \mathrm{D}$ printer, it is possible to print the desired 3D model. Once the model has been printed, it will be possible to grind the model to the desired shape or add it to the acid to remove excess material.

Nextion display as a smart HMI display has its own IDE. The desired results will be displayed using a program created in the Nextion Editor program. The desired information will be displayed using information obtained from the Windows application or from the web remote server.

The Visual Studio 2019 development environment and $\mathrm{C \#}$ programming language will be used to create a Windows application supporting property checking mode of IoT.

The department keeps an information about asset in database on central server. Obtaining data from a remote database is a process that consists of several parts and can be solved in different ways. One of common ways is to read the data from the database using PHP scripts present the data in XML or JSON format. The data are located on the servers with installed Apache, PHP and MySQL services. As a more effective way JSON format was chosen. The IoT device can read JSON data to identify the device already scanned in "location mode" or desktop application to synchronize the local database with the central one. The ERA diagram of the department asset is shown in Fig. 9.

The database serves originally for web portal [5] for where additional functionalities are supported for instance device lent by employee for specific project so other employees know that the device is occupied or writing comments for specific device etc. For asset control IoT application not all data from the database are required. Necessary data for asset control IoT are stored in the tables ktpe-record and ktpe_namespace. The first table contains the core information as are name, designed location and also identification number coded in barcode. The designed room in the table is defined by room id. Therefore there is second table with namespaces where id of the rooms connected with different rooms and laboratories name known by employees and students. 


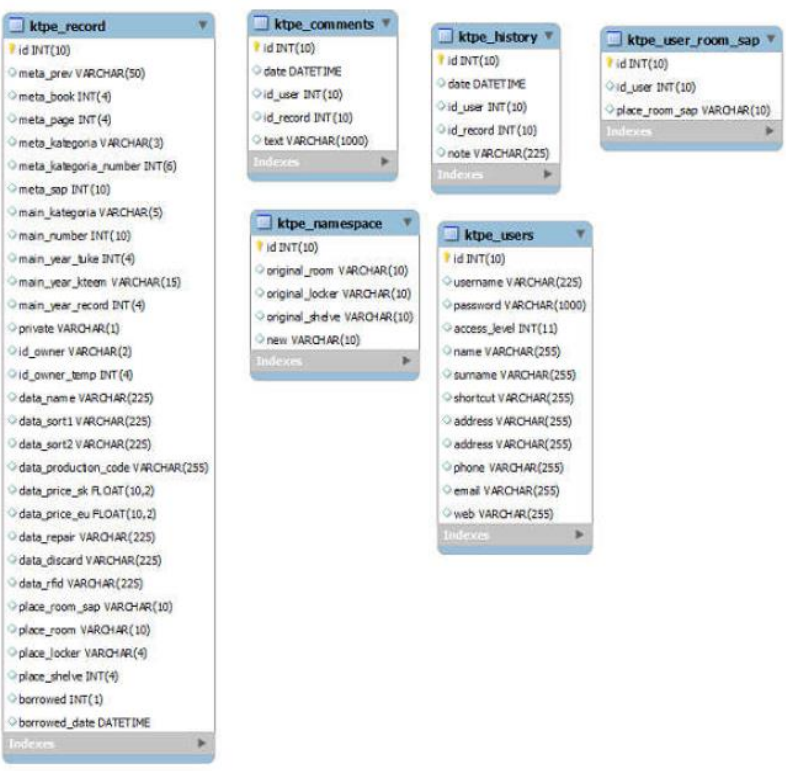

Figure 9 - Department asset database ERA diagram

\section{Hardware part implementation}

After selecting the reader module, it is necessary to connect the module with a microprocessor for proper operation and overall IoT setup. The module could be connected in several ways, either directly to the PCB or using a module with an FPC connector. In the first case, a bilateral PCB would have to be designed, but the second option follows from the proposal. The reader module is connected via a flex cable, which is of sufficient length for handling even in less accessible places regarding the size of the overall cover of the device. The FPC board is soldered connectors with the possibility of connection to the ESP microprocessor using connecting cables. The FPC board is double-sided because it is universal for two types of flex cables ( $1 \mathrm{~mm}$ and $0.5 \mathrm{~mm})$. In our case, the side of the flex cable with a pin width of $0.5 \mathrm{~mm}$ was used. FPC pins reverse arrangement with respect to the opposite side of the board. For testing, a microprocessor is connected to the contact field, where the modules are connected by connecting cables. The proposed connection was tested by connection in the contact field. The verified connection using the contact field is shown in Fig. 10.

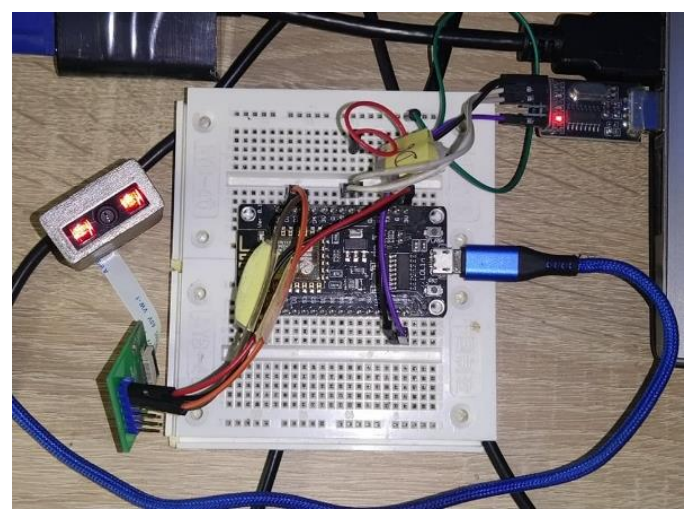

Figure 10 - Department asset database ERA diagram
Nextion Simulator, a built-in tool from Nextion Editor, was used to test the display module. The connection of a PC with a contact field was made using a USB - TTL converter. The reader module is connected by 4 pins to the microprocessor on the contact field. To pins 3V3, GND, D1 and D2 (Tx, Rx). The display module (USB - TTL for testing) is connected to the microprocessor by pins VIN, GND, D5 and D6 (Tx, Rx). The digital pins are used for the ESP8266 UART communication with Nextion display modules and CCD readers using the SoftwareSerial library. To develop and debug the software, it was necessary to connect a microprocessor and USB - TTL to a PC. The PC uses two COM ports, where the first communicates with the microprocessor and the second communicates with the Nextion Editor.

The PCB design includes all components of the IoT device, it is a modular connection, module TP4056, DC-DC converter will be part of the PCB. Figure 11 shows a modular PCB to which a TP4056 charging module and a DC-DC converter have been soldered. Subsequently, pins 2x15 for the ESP8266 NodeMCU v3 microprocessor, $1 \times 4$ for the display module and $2 \times 6$ for the reader module were soldered. In case of failure of the microprocessor or any of the modules, it is possible to replace the module thanks to the pins, no re-soldering is necessary.
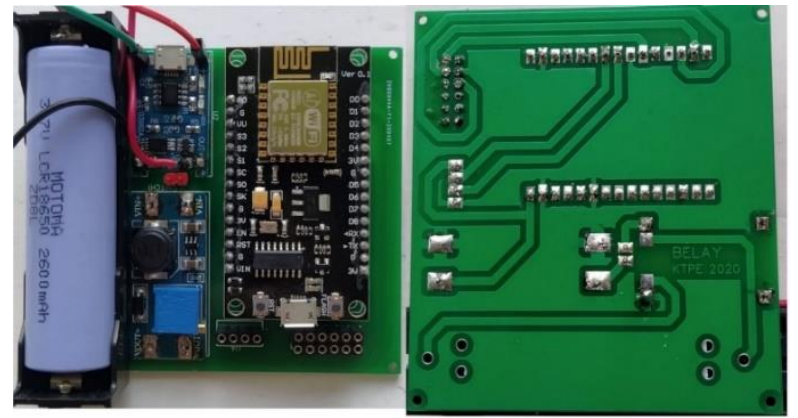

Figure 11 - PCB mounting

The resulting cover for the property registration device consists of several parts. These parts are screwed or slid together, according to the respective part of the cover, and form one unit. The folded and unfolded reader module cover is shown. The cover itself shown in Figure 12 and it consisting of two parts, where the first part forms the housing of the device and the second part slides into the first part from the back with a hole for a flex cable for connection to the FPC board and subsequently the PCB.

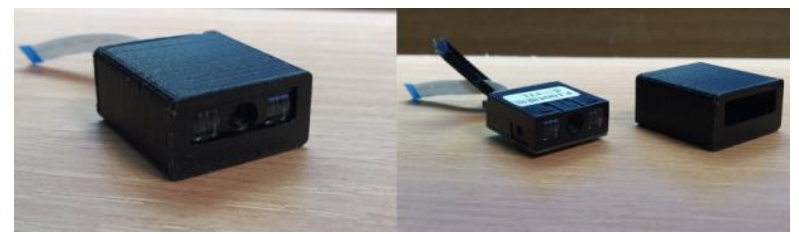

Figure 12 - Cover for module of barcode reader 
A printed cover of a 3D model of the Nextion display is shown in Fig. 13, where the display itself is in the central part of the cover. The display module is screwed to the cover with respect to the space between the display surface of the display and the cover. Its dimensions are $105.5 \times 70.5 \times 6 \mathrm{~mm}$ and the cover are adjacent to the main cover. If the screws are too tight, the cover touches the contact surface and it does not work in such an example, or it is possible to add washers between the display and the cover. There are 4 outputs from the display, which will be soldered to the PCB. After printing the covers, the models had to be fine-tuned with a file to remove excess material that was part of the cover for good stability of the model during $3 \mathrm{D}$ printing. After printing, you can see subtle shortcomings in the printing of the G-code design, so when finalizing the device, the paint is applied to the covers themselves. There are two ways to load a program GUI from Nextion Editor to the Nextion display. The display contains a component for the SD card. The first way is to insert the SD card with the recorded program, the second way is to load the program via the COM port from the PC.
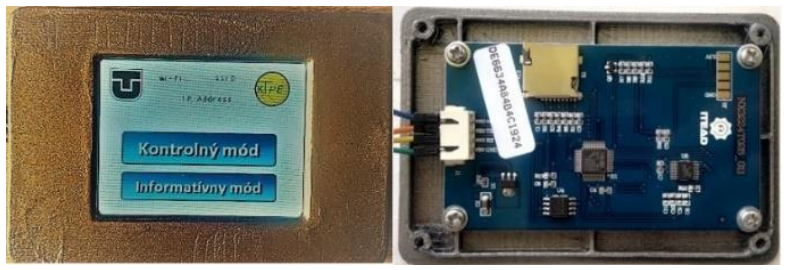

Figure 13 - Cover for module of barcode reader

The final cover consists of several models, which includes the cover of the reader module, the cover of the display module, the department's (KTPE) logo, the handle for the cover of the reader module. This clip is glued to the main overall cover and there is the possibility of attaching the reader to the cover when the device is not used by the user. A screw is screwed to the bottom of the cover to close the overall cover. It is screwed with 4 screws, also with legs, which create the profile of the stand. Much of the model, in which all the modules that make up the IoT device are embedded, needed to be modified. It was necessary to adjust this with a file to smooth out excess material, but also by milling excess material. 4 holes were drilled and with the help of these holes, it was possible to cut the excess material by joining the holes by cutting. In Figure 14 shows an IoT device at various angles in an enabled information mode that can be used without the use of an application.

This process was used to create a switch hole that is soldered to the designed switch on the PCB. You can use the switch to turn the device on or off. The switch can be used to connect or disconnect the circuit between the TP4056 module, which is powered by the 18650 battery, and the DC-DC converter, where the circuit continues to the microprocessor and the module. In this way, it is possible to charge the battery even when the switch is "OFF". The cover has 5 holes. Input for microUSB cable for charging the battery or powering the device when the battery is fully charged. Input to turn the device on or off by the user. A hole for the flex cable used to connect to the reader module and output in the form of a display to display the necessary information in the form of a device mode. The overall cover has dimensions of $110.5 \times 105.5 \times 45 \mathrm{~mm}$, which represents a slightly larger dimensions of the overall device. The solution was designed and made by a separate part of the reader module from the overall device. The cover of the reader module has dimensions of $32 \times 29 \times 15 \mathrm{~mm}$ and in connection with a longer flex cable it forms small dimensions, therefore it is possible to scan even less accessible places. A longer flex cable is not available in the current situation, but over time it is possible to mediate the cable and the inspection will be possible in less accessible places and it will fulfil the function of a separate cover of the reader module. When creating an application, it is possible to continue and add various more elements to the inspection process, add more automated elements or create more graphical environments to create MENU applications with different selections.

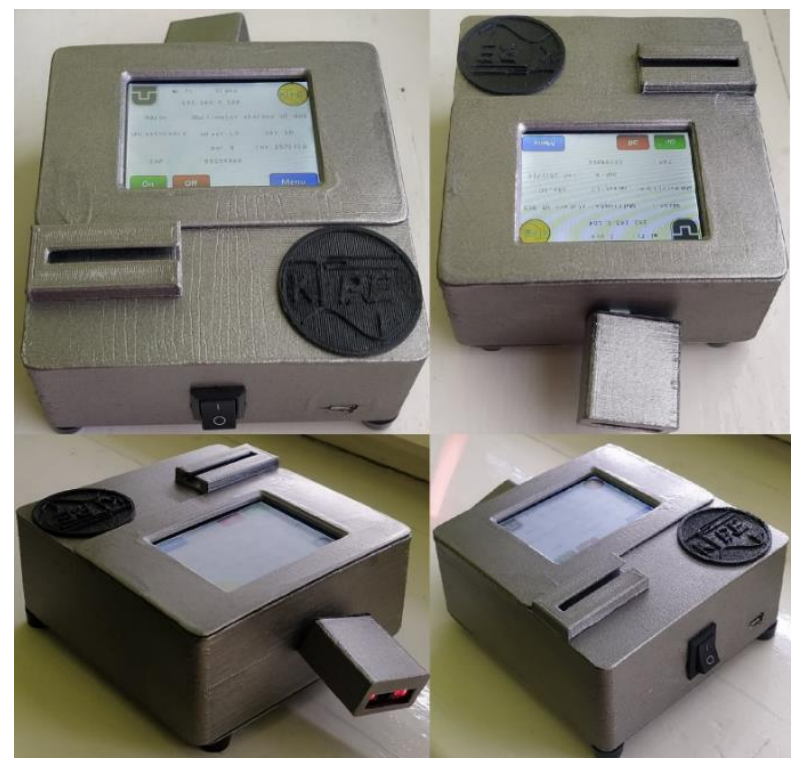

Figure 14 - Final IoT device in 3D printed cover

CONCLUSION. The project proposal was first made up of several sub-factors that are linked to each other and together form one whole. It was very important how the factors of the project itself would be made clear and prepared, as this will ensure the entire operation of this facility to support asset records. All these factors needed to be very thoroughly clarified. The client-server application was designed to support the control of property records with the design of IoT equipment. By studying the issue of obtaining data from a remote database, it is possible to make data available for the application and the IoT device. The application can update the local database according to the remote database. Several programs and programming languages 
were used in the work and this provided experience with the use of knowledge. Familiarity with the barcode, its types and standards and the reader modules themselves. An important factor is the importance and potential of IoT devices today and the need for constant study of technology. The design of IoT devices is realized by modular connection of components. By implementing the GUI on the display, it is possible to control the reader module and observe the records in the informative mode and the control mode. 3D models are a device in a housing, where the output is a display. The switch can be used to change the on or off state. The device is fully mobile using batteries and charging is solved using a micro-USB cable. The reader module is separate from the device and it is necessary to provide a longer flex cable to make the use of the device more efficient in less accessible places. Using an application in the Visual Studio 2019 development environment, it is possible to connect to an IoT device and perform asset registration control by communicating with each other.

\section{REFERENCES}

1. Nuțiu, Denis (2018). How to get started with FreeRTOS and ESP8266. URL: https://www.freecodecamp.org/news/how-to-getstarted-with-freertos-and-esp8266-7a16035ddd71/

2. Moyer, Philip (2020). Programming the ESP8266 With Lua URL: https://learn.adafruit.com/diyesp8266-home-security-with-lua-and$\mathrm{mqtt} /$ programming-the-esp8266-with-lua
3. Damien, P. George, \& Paul, Sokolovsky (2020). Programming Language MicroPython for device ESP8266. URL: https://docs.micropython.org/en/latest/ esp8266/tutorial/intro.html

4. ArduinoIDE software from Arduino. URL: https://www.arduino.cc/

5. Tomáš Herich (2011). Web database portal for asset management, Bachelor thesis, Košice.

6. Nextion. URL: https://nextion.tech/

7. Nextion Display with Arduino. URL: https://randomnerdtutorials.com/nextion-display-witharduino-getting-started/

8. Bereš, Matej, \& Slavko, Olena (2019). Four Leg Interleaved DC-DC Buck-Boost Converter with Modifiable Topology Using Proposed Windows Application. IEEE International Conference on Modern Electrical and Energy Systems (MEES). 214-217.

9. Molnár, Ján, Lorinc, Tomáš, \& Slavko, Olena (2019). Design and Implementation of an Intelligent Air Quality Sensor. IEEE International Conference on Modern Electrical and Energy Systems (MEES). 74-77.

10. Molnár, Ján, et al. (2017). Design of motor speed controller of electronic commutation. International Conference on Modern Electrical and Energy Systems (MEES). 276-279.

11. Bereš, Matej, et al. (2017). Current ripple comparison of multi and single phase buck-boost converters. International Conference on Modern Electrical and Energy Systems (MEES). 260-263.

\section{МАЛОБЮДЖЕТНАЯ ІОТ-СИСТЕМА ДЛЯ КОНТРОЛЯ ОБОРУДОВАНИЯ НА ОСНОВЕ СКАНИРОВАНИЯ ШТРИХ-КОДА}

\section{Т. Винсе, Л. Белай}

Технический университет Кошице

ул. Летна, 9, г. Кошице, 04200, Словакия. E-mail: E-mail: tibor.vince@tuke.sk, lukas.belay@student.tuke.sk

Работа посвящена анализу работы и внедрению ІоТ-системы для поддержки контроля учёта оборудования в лаборатории на основе сканирования штрих-кода. В статье приведены результаты анализа возможности разработки ІоТ-устройства для поиска правильного места хранения приборов в лаборатории и поддержки проверки принадлежности определённого устройства выбранному месту расположения. Предложено один из возможных вариантов разработки ІоТ-устройства на основе микроконтроллера ESP8266 с использованием «умного» дисплея Nextion и Windows-приложения, разработанного с помощью С\#. Получая данные из удалённой базы, приложение обновляет базу данных ІоТ-устройства с центрального сервера. Авторы описали весь процесс разработки, начиная с компьютерного моделирования предложенного ІоТ-устройства, выбора элементной базы, проектирования и разработки Windows-приложения, а также экспериментальные исследования полученных результатов. В работе предложено экспериментальный образец ІоТ-системы для помощи контроля устройств и приборов в лаборатории на основе сканирования штрих-кода. Для поддержки контроля корректности записей в базе данных ІоТ-устройства было разработано соответствующее клиентсерверное приложение. Структура ІоТ-устройств была реализована на основе принципа модульного соединения компонентов. Используя графический интерфейс пользователя, есть возможность управлять модулем считывания и читать записи в базе данных в информационном и управляющем режимах. Для дисплея созданы трёхмерные модели помещения, в которых отображается расположение контролируемых приборов. Используя разработанное приложение существует возможность соединяться с ІоТ-устройством и выполнять регистрацию и управление приборами путём организации коммуникации устройств между собой. Разработанная система внедряет все теоретические результаты исследований, описанные в статье, и подтверждает их на основе проведённых экспериментов. Предложенная ІоТ-система может иметь практическое применение, например, для контроля местоположения оборудования в лабораториях университета в любой момент времени.

Ключевые слова: C\#, IoT, Nextion, ESP8266, штрих-код. 